\title{
RESEARCH
}

OPEN ACCESS

\section{Education for Peace: Transforming the Culture of Violence}

Aparajita Sharma ${ }^{\dagger}$

\section{Abstract}

The paper narrates the conceptual framework of 'Education for Peace' and its need especially in regions, which have seen ethnic conflicts. In Education for Peace, the educator and the educand are seen as transformative agents and not mere passive recipients. Their role is not restricted to the close precincts of the classroom and the 'schooled' world but to the larger community and the lived experiences of the educand and the educator. Its importance in the curriculum of school education is widely felt as well. In conflict prone or post conflict regions where collective memories of the past conflict and collective hopes of the future are contested, understanding the views and collective hopes of the 'other' becomes imperative. In this context, I would like to explain the concept of 'Education for Peace', its approaches and prerequisites and locate the contesting spaces, structure, content, images, processes in school education by reviewing empirical and theoretical studies on 'Education for Peace'. It further delves into ethnicity and ethnic conflicts and probes how it makes different meaning in different contexts. The paper leaves scope for exploring educator-educand relationship, identity construction rather reinforcement though school education for transforming violence of culture in regions which is facing identity crisis and conflict.

Keywords: Education for Peace, ethnic conflict, culture of violence, educator-educand

\footnotetext{
${ }^{\dagger}$ Department of Social Work, Delhi University, India [Email: aparajitasharma07@gmail.com] (C) 2013 Sharma. This is an Open Access article distributed under the terms of the Creative Commons Attribution License (http://creativecommons.org/licenses/by/2.0), which permits unrestricted use, distribution, and reproduction in any medium, provided the original work is properly cited.
} 
Sharma. Space and Culture, India 2013, 1:1

http://www.spaceandculture.in/index.php/spaceandculture/article/view/15/5

\section{Introduction}

Education plays a central role in promoting relations and reconciliations, in society with a history of ethno-conflict, have been acknowledged frequently in the academic literature and increasingly in national and international policies. Peace education has thus been incorporated explicitly and implicitly in curriculum of post conflict societies around the world and is particularly pertinent in subjects like history and citizenship education. Its importance in the curriculum of school education is widely felt and especially in conflict prone regions. In conflict prone or post conflict regions where collective memories of the past conflict and collective hopes of the future are contested, understanding the views and collective hopes of the 'other' becomes imperative. In this context, I would like to explain the concept of 'Education for Peace', its approaches and prerequisites and locate the contesting spaces, structure, content, images, processes in school education by reviewing empirical and theoretical studies on 'Education for Peace'. Critical peace education, peace oriented learning have also been mentioned because of its similar meaning and purpose.

Many educationist and theorists particularly Michael Apple, Paulo Friere, John Holt, Alexander Sutherland Neill, Jiddu Krishnamurthy, Krishna Kumar, Henry Giroux, Antonio Gramsci, Johan Galtung and the like offers a framework for peace-oriented learning. Education has always been considered a major state intervention for peace building in the society. The concept of 'Education for Peace' evolves from the Charter of the United Nations that was signed on June 26, 1945 in San Francisco to prevent any global conflict further. It reaffirms faith in the fundamental human rights leading us to practice tolerance and live together in peace with one another as good neighbours. The Universal Declaration of Human Rights (UDHR) is an important document, though not legally binding. It is also important for critical peace education because it recognises the existence of tension and conflict among various groups for power. As early as 1950, Herbert Read defined Education for Peace in two ways. Firstly as a "process of education meant to make people more peaceful. Such education has to be reformative. There is another process of designing education for men at peace. This would mean bringing up children in a positive frame of mind in social unity and creative activity" (Read, 2012: 13). The NCF (National Curriculum Framework), 2005, India concentrates on construction of knowledge which encourages student's participation as well as inclusion of student's ideas, beliefs and experience in the classroom discussion. One of its core concerns is 'Education for Peace' because of its immediate relevance in the society. It says 'Education for Peace' is a precondition for national development in view of growing tendency towards intolerance and violence (NCF, 2005). On similar lines Justice Verma Report (2013) on the Amendments to Criminal Law drafted after the national furore against the Nirbhaya (Fearless) Rape and Murder case, which happened at the heart of the capital city in India suggests remedies to counter gender violence in the country. One of the many suggestions of the very well drafted and well-intentioned report was that "schools have to act as countersocialisers to tackle gender bias and discrimination" (Kumar, 2004 cited in Verma et al., 2013: 396). It further talks about the larger role of the school in addressing concerns of masculinity and femininity by experiencing ascribed gender roles by both male and female. The wider aim was to build a culture of tolerance and equality to counter the ever-burgeoning violence in everyday life.

In India, violence has been increasing to a feverish extent across the country. In recent times, India has witnessed worst forms of 
gender, ethnic and communal violence. The capital city of Delhi and gender violence has become synonymous lately. The Nirbhaya case is just one example. Delhi is not an exception in cases of ethnic and communal violence. Reference of North-Eastern people of India as 'Chini, Japani' (belonging to China and Japan) in Delhi reflect not only their lack of knowledge but also their perception about 'identity' and 'culture' of a particular group of people. This may not be a case of direct violence but acts adversely towards peace in the region.

The kind of violence North East region has witnessed due to years of maginalisation, that have raised its head in the form of movements and ethnic conflicts which invariably have an impact on the children born in this region. Their identity of self, 'others' and 'significant others' is constructed through the interplay of various factors. This review paper centres on this main concern of how Education for Peace can address core issues of conflict, counter culture of violence and construct peace in a dialogical manner. It further discusses concepts, approaches of Education for Peace, key issues, ethnicity and school education and how Education for Peace could be best understood with knowledge of the socio-cultural-historical locale of a region for transforming extant violence of a place into culture of peace. Apple and Bean (2006: 83) have given conditions, which fulfil the foundations of a violence free and democratic way of life to counter subverted democracy.

- The flow of ideas, regardless of their popularity, that enables people to be as fully informed as possible.

- Faith in the individual and the collective capacity of people to create possibilities for resolving problems.

- The use of critical reflection and analysis to evaluate ideas, problems and policies.

\section{Understanding 'Education for Peace'}

Education for Peace does not have a very long history and compared to many discipline is of recent origin. Its origin could be traced back to post World War II in1945 However, various definitions have been given by many academicians as well as practitioners during the course of time. Perhaps peace is like happiness, justice, health and other human ideals something every person and culture claim to desire and venerate but which few of any achieve at an enduring basis. Peace is a linchpin of social harmony and economic equity and political justice. Nevertheless, peace is also completely ruptured by wars and other forms of violent conflict. Like love, peace remains so close yet like enduring love so far. Scholars like (Webel and Galtung 2007; Galtung and Vincent, 1992) talks about positive and negative peace. Positive peace refers to a holistic approach towards peace where there is absence of both direct and structural violence. Negative peace refers to the immediate stopping of violence where the visible violence is given more importance. Galtung and Vincent (1992) go on to talk about building a culture of peace as an indicator of positive peace in the society.

Burns and Aspeslagh (1996) identified the following features of peace education

- Peace education is aligned with a radical/counter hegemonic paradigm for social change through education.

- Peace education, to which they couple international education, can be analysed as a strand of comparative education.

- The core conceptual components of peace education were developed particularly through the writings, conferences and pedagogical practices of members of the Peace Education Commission of the International Peace Research Association.

They identify the roots of peace education in 'world education' but they also frame their work 
in peace education as acts of resistance to dominant models of education that produce oppressive, violent social structures. Several other articles written by them also position peace education as radical and indeed oppositional to mainstream education. The works of Elise Boulding and Paulo Freire could be mentioned in this context. Boulding (1976) was acknowledged for theoretical feminist peace theorising about personal and interpersonal violence and her emphasis upon future thinking and the key role of international nongovernmental organisations (NGOs) in promoting peace. Paulo Freire contributes an emphasis upon developing a questioning attitude towards the violence of the status quo and a pedagogy that relies upon a dialogue between teacher and pupil where both together seeks alternative to violence. Peace educators produce critical thinkers who question the emphasis upon militarism found all around the world. Upholding the concept of Education for Peace by Jiddu Krishnamurthy, Kumar (2007: 128) reiterates how it is important to overcome 'narrow nationalism'. He adds further:

"No one feels quite certain that nationalistic fervor can be created in children without at least a symbolic invocation of threat" (Kumar, 2007:128).

Earlier, scholars like Gramsci and Giroux gave a detailed explanation of these ideas: they elucidated as to how school through various social processes reproduce forms of cultural capital i.e. system of abilities, language forms, tastes etc of the dominant cultural group. Gramsci (Hoare and Mathew, 1977) called this 'ideological hegemony', a form of control, which not only manipulates consciousness but also saturates and constitutes the daily experiences that shape ones behaviour. As Richard Johnson (cited in Apple, 1982: 32) notes

"It is not so much a question that schools......are ideology, more that they are the sites where ideologies are produced in the form of subjectivities".

This makes a person's identity dependent on the technical skill that he possess. An unskilled person thus loses his identity and name in the society. This legitimises inequalities in the society and recreates it through a process of 'particular social construction.

It is an interesting exercise to assess the status of peace education within this framework for a philosophy of education. While there, is no one particular philosophy or philosopher but as Burns noted:

"I contend that a basis for distinguishing and developing perspectives is a view of the nature of the human being of our relationship with the world in which we live, and of process of change" (Burns and Aspeslagh,1996: 362).

Approaches to 'Education for Peace' have been descended from the progressive educational tradition of Jean Jacques Rousseau, John Dewey, Alexander Sutherland, Neill, Ivan Illich and Paulo Friere as explained above. In this conception, humans are born neither as passive nor without any intrinsic morality. The core role of nonviolence in peace education is rooted in this conception of human goodness, such that individuals find their identity and expression through adhering to non-violence. Freire (1973) emphasised on this concept, which reaches its fullest expression in the understanding of humans as social, collective, political beings with the basic tendency towards cooperation with each other in the construction of peaceful societies. Bajaj (2004) beautifully described four approaches mentioned by Haavelsrud (1996). She writes that he created for instance a typology on different interests of knowledge as reinforcing, reforming or transcending and commented that "the reinforcing interests sees to it that evaluation of knowledge is performed by experts in specialized fields of expertise"(Bajaj, 2004: 13). Haavelsrud further 
argued that such views through the sorting of everyone into categories based on system preferences (e.g. class, gender, race) stifle social change and the achievement of peaceful societies. In another schema of peace education, Toh and Cawagas (1990) diagrammatically represented elements of peace education knowledge as holistic (Figure1).

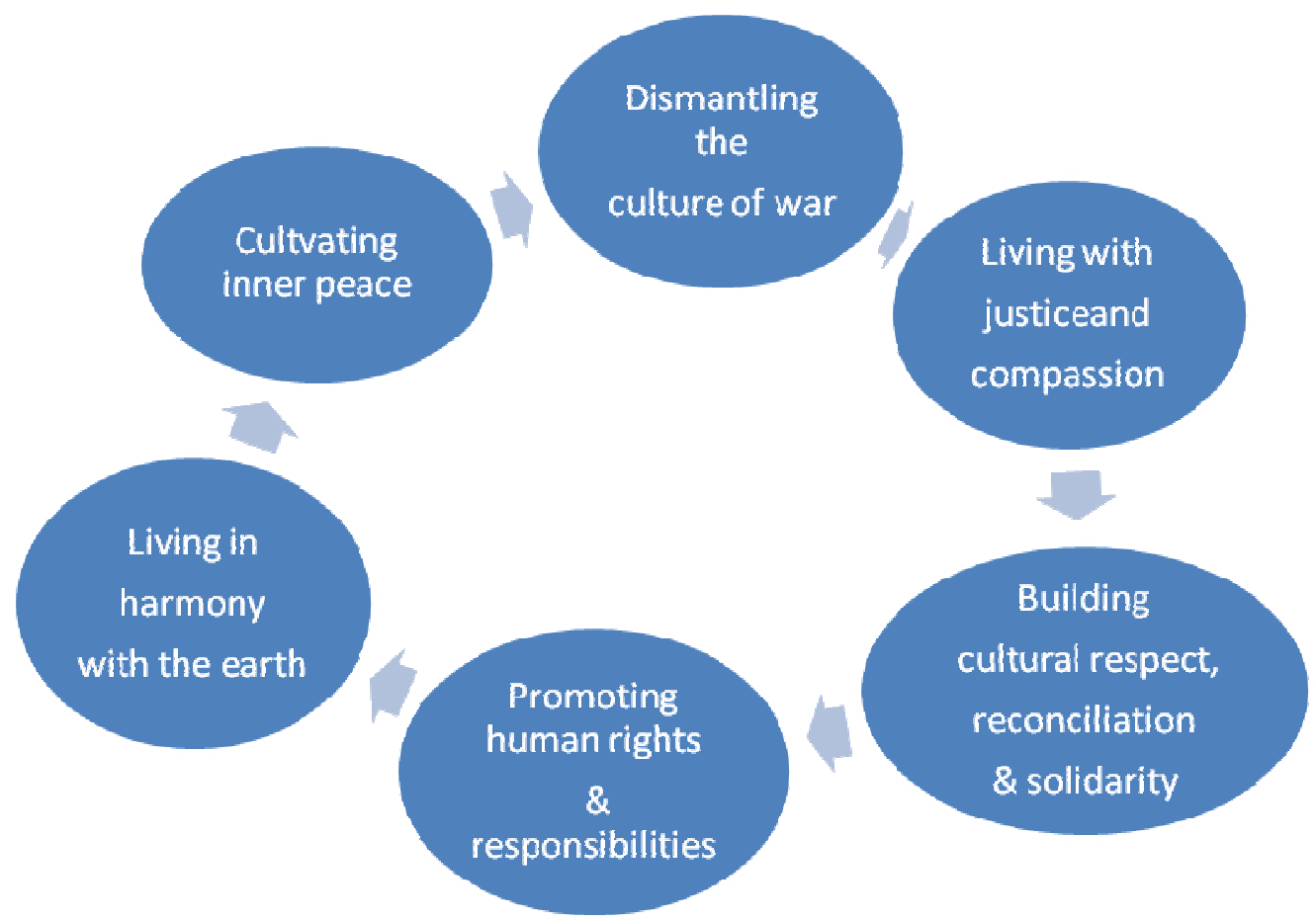

Figure 1: A Holistic Framework of Educating for a Culture of Peace

Source: Toh, S.H. and Cawagas, V. (1990: 20). Peaceful theory and practice in value education

Haavelsrud mentioned four types of approaches viz. idealist, intellectual, ideological and politicisation approach. The idealistic approach in which there are universal notions of problems and solutions and little attention is paid to distinct societal groups and their interactions. Haavelsrud (1996) cites the UNESCO preamble as representative of this approach, which asserts that wars begin 'in the minds of men' and therefore, the singular new generation, versus the 'old,' needs peace education to counter the violent tendencies throughout the world. The level of analysis is the individual and there is a focus on social cohesion. This approach, often espoused by the NGOs and international initiatives, ignores issues of structural inequalities in formulating peace education and arguably, may exclude action to promote peace (Bajaj, 2004).

The intellectual approach talks about multiculturalism, pluralism, however without addressing the conflicts within the system. The ideological approach emerges from the writings of neo-Marxist analysis of schooling, which is based on counter hegemonic intervention processes of building Education for Peace (Burns and Aspeslagh, 1996). The last approach is based on Friere's politicisation approach with the focus on critical consciousness and agency of the educators and educands for transformation and co-construction of knowledge rather than being mere recipients of educational policy and curriculum content. Previous study has reported on critique of social conditions (Wulf, 1974). 
Cultural and critical perspective of peace education evolved from the writings of these authors. While the field's evolution reflects the conditions of the time, in the present age of globalised economic and political structures, that are increasing disparities and simultaneously dismantling avenues for citizens to hold their governments accountable, it appears that renewed attention to larger structural realities, particularly in the global south and through engaged and systematic research, would prove beneficial in understanding the possibilities and limitations of peace education. Hence, acknowledging the need for a critical approach to peace education that affirms diversity and a multiplicity of perspectives is important to outline the components of such an approach.

The primary purpose of peace education should therefore be to build people's capacities to recognise, confront, and transform the culture of violence. "Central to such a challenge is providing students with the skills, knowledge, and authority they need to inquire and act upon what it means to live in a substantive democracy...to fight deeply rooted injustices in a society and world founded on systematic economic, racial, and gendered inequalities" (Giroux, 2001: 114). Peace education should therefore be studentcentered, a process of mutual learning among educand and educator. As stated above, NCF (2005) too was drafted to make curriculum more flexible and student -centred, which is turn is believed to be a medium to promote peace. It also emphasises that all children are motivated and capable of learning. Children learn in a variety of ways. Developing capacity for abstract thinking, reflection and work are most important aspects of learning. Child is seen as a 'critical' learner and constructor of knowledge along with the teacher.

\section{Emerging key issues}

Education for Peace thus particularly looks at educational schools as a "site for positive attitudinal change without negating conflict but by providing a space in terms of content, communication form in relation to contextual conditions within which education action takes place" (Webel and Galtung, 2007: 238).

Galtung and Vincent (1992) have offered the following comprehensive definition of peace with eight components. Human needs can be grouped into four basic categories: survival, economic well being, freedom and identity (the opposition of death, misery, oppression and alienation). They are threatened by four forms of violence: direct violence (killing people, putting villages aflame, in the name of ethnicity as in the case between Bodos and Muslims and Bodos and Santhals in Assam,); structural violence I (Unemployment or underemployment of educated youth in India, starvation deaths, poverty, lack of knowledge and technological know- how); structural violence II (deprivation from freedom of choice and from participation in decisions that affect people's own lives) and cultural violence (rape, assault or public outrage of a woman as in the case of Nirbhaya in Delhi, or comments, gestures on women from North East India in the capital city of Delhi due to imposition of mainstream culture and ignorance of the cultural capital of the North eastern people). There is also a broad correspondence between these four forms of violence and the four basic forms of power: military, economic, and political and cultural.

Critical approaches offer peace educators and researchers the contextual and conceptual resources to understand the structural impediments to advancing peace education in diverse locals across the globe. Rather than status-quo reproduction critical approaches in peace education and peace research aim to empower learners as transformative change agents (Freire 1970) who critically analysed power dynamics and intersectionalities among race, gender, ability/disability, sexual orientation, language, religion, geography and other forma of stratification reinforcing ethnic identities. Learning theorists, researchers and practitioners 
in the field of peace education and peace studies have consistently highlighted the necessity of comprehensive approaches for a culture of peace. Several scholars have argued for a critical peace education that pays attention to methods, content and organisational structure and truly addresses the ways in which both direct and structural violence manifest personally and in society at large (Haavelsrud, 2008; Hicks, 1988 and Reardon, 1988)

\section{Ethnic Identity and Education for Peace}

Theoretically, Max Weber (1968) among the classical sociologists found space for the concept of ethnic group. He called ethnic groups as "those human groups [who] entertain a subjective belief in their common descent because of memories of colonisation or migration" (cited in Barth, 1969: 118). Weber wrote about three approaches of ethnicity viz. social construction, primordial and instrumentalist approaches. He tried to show that ethnic groups are socially constructed and that the contents of the group in terms of both culture and personal have not priori-existence or stability (Barth, 1969). The primordial approach is different which believes that ethnicity is an innate aspect of human identity. On the other hand, the instrumentalists approach is close to social construction, which holds that ethnicity is an artifact to bring together a group of people for some common cause. In India, the concept of ethnicity is often linked with tribe. However, it should not be interpreted that tribes and ethnic groups are same. In the United States of America, the concept is generally used to refer to the Jews, Italians, Irish and other people considered inferior to the dominant group. It may be primarily decent, religion or language (Nongbri, 2005). For a rounded understanding of ethnicity, Richard Jenkins (2008:13) has spelt out the following basic anthropological model of ethnicity.

Ethnicity is about cultural differentiation (bearing in mind that identity is always dialectic between similarity and difference). Ethnicity is centrally concerned with culture, shared meaning, but it is also rooted in the outcome of social interaction. Ethnicity is no more fixed or unchanging than the culture of which it is a component or the situations in which it is produced and reproduced. Ethnicity as a social identity is collective and individual externalised in social interaction and internalised in personal selfidentification.

The understanding of individual and collective identity is crucial to the understanding of ethnicity. To preserve their identity they use symbols, language, religion, celebration of festivals etc. Perceived cultural differences in the social setting play significant role in the emergence of identity. The perceived and manufactured differences are carefully worked upon by the organisations and agencies whose aims are met successfully by these divisions. Social distance among different groups of people is still prevalent in the veneer of a socialist, secular democratic state.

The combination of religion and nationalism is a particularly powerful response ("identitysignifier") in times of rapid change and uncertain futures, and is therefore, more likely than other identity constructions to arise during crises of ontological insecurity (Kinnvall, 2004). The movements out of such insecurities are treated as law and order problems and dealt with it. Inequality in society is often not seen with tolerance and empathy rather with degradation and brutality. Such movements are propelled by a contest over resources in ethnic homelands that are then sought to be populated by a militarily dominant ethnic group. The call to arms therefore is a real tangible artifact of a policy framework within which competition is articulated along ethnic lines and sought to be resolved along military ones. The emergencies of ethnic militia therefore, could be seen as an outcome of a dual process of impoverishment and militarisation where small communities have 
to arm themselves to prevent a complete assimilation of lifestyles, culture and resources. Such militant reactions are seen as manageable conflicts by policy makers. Most accords between the central government and agitating group skirts other issues and pick on economic grievances in order to deal with the unrest.

A process of selective engagement with inscribed rules for articulating dissidence emerges as models to be emulated in future deliberations and other recalcitrant communities. Economic packages have been the preferred issue in the course of deliberations between the government and the ethnic groups. This causes conflicts to reemerge later. This is typified in the conflict in western Assam where ethnic Bodo people have waged a two-pronged struggle against the Indian state, which is seen as an external colonial entity responsible for the loss of resources and culture of the Bodo people. The other strand of the armed struggle sees the state as a logical arbiter in the contest for an ethnic homeland. In 1993, the Central government herded the Bodo leaders who had sent friendly and frequent feelers for an honourable resolution of the conflict as well as the government of Assam to sign on to what came to be known as the Bodo accord in Kokrajhar. Conflicts surrounding the identity of a group get violent, which may not be visible but also expressed through spaces, institutions, public space and family (Datta, 2012).

The Bodo tribe comprises of many other subtribes and are the original inhabitants of the Brahmaputra Valley in Assam. Like many other ethnic groups, Bodo lost their identity in colonial and post colonial Assam mainly because their indigenous ways and expertise served no good for the British. The political movement in the late $20^{\text {th }}$ century from eighties was the greatest human struggle and it ran into the $21^{\text {st }}$ century. This struggle is known as the Bodoland Movement (Brahma et al., 2001).

The Bodoland movement is an effort to assert their lost identity, which is supposedly the earliest inhabitant of today's Assam. Their culture, value system, language, knowledge system have been marginalised in post -colonial Assam. In this context 'Education for Peace' would help us locate ideology in school education, reinforce mainstream culture or reflect the lived experiences of the educands and educator, dialogue on issues of conflict, violence , identity etc. Many educationists have argued that classroom ritual in St Ryan worked to reproduce and reinforce existing patterns of class and ethnic dominance (Bernstein and Landis 1974: 37; McLaren, 2002). The kind of knowledge, which is inexorably transmitted also, sponsors a culture, which is familiar to a few. There are many other studies which show that schools are not neutral agencies but promote interests of dominant groups in the society (Karabel, and Halsey 1977; Apple, 1982; Kumar, 2001 et al.). In her study, Angela Little recorded that just "6.1\% of empirical work between 1977 and 1998 dealt with "curricular content and the learner's experience as compared with nearly $31 \%$ on themes such as educational reform and development" (Little, 2000: 283). Robert Cowen asserted that "we are nowhere near coming fully to grips with the themes of curriculum, pedagogic styles and evaluation as powerful message systems which form identities in specific educational sites" (Cowen, 2000: 340). There are evidences as in Northern Ireland of a desire to distance the state from a direct role in reinforcing the religious dimension of cultural identity. Despite the withdrawal from religious education, the rules of the Department of Education for vocational schools, which are under the control of local authorities, endorse a view of religion as an integral part of the cultural identity to be promoted in these schools. In a multiethnic society, conflict is often a powerful aim around which life theories are told. As we engage in conflict, our narratives evolve the way we tell our past understand our present and prepare for our future -often shift (Rothman, 1997: 34). There is perhaps nothing as powerful 
for defining, enriching and deepening identity as identity over conflict, which has been established by the texts referred above. School as a moral community shows appropriate sentiments towards a dominant value system of the wider society. In case of Bodoland, movement schools in these regions and the culture they promote among students could be an area to understand identity building of children in this area, which may reinforce or marginalise a particular group.

More recently, scholars have linked Paulo Freire's educational philosophy to peace education and titled it "critical peace education" (Diaz-Soto, 2005). Earlier, such philosophies were discussed in detail by Wulf (1974). While addressing wars that continue to be fought worldwide, Diaz-Soto grounds her call for a critical peace education in the United States based on a need to promote negative peace, or the absence of direct violence. Her recommendations to educators are rooted in a Freirean analysis of power with the aim of consciousness rising: she further calls for "border crossing," "decolonization," "inclusion," "equitable economic distribution," and reliance on "love as a paradigm" (Diaz-Soto, 2005: 96). Some of her analyses resonate with the ideas put forth in this article, particularly the call for attention to power, identity, culture and deconstruction of the hierarchical relation between the educator and the educand. This leaves scope for more and more empirical research based on the localised context of any conflict, school education and agency of the educator and educand to question the status quo.

\section{Conclusion}

Education for Peace makes various meaning depending on the context, history and location of a school. Children are not passive objects. They are living beings learning to cope in a strange world. As culture is a learned behaviour, it is important for the agents and actors in their life especially teachers who are carved out for this role to help them make meaning of the world together with them. Listening to them is as important as telling them. Are our educators listening to the educands or considered worth listening? Is the meta narrative of narrow nationalism excluded from the group the educands belong to? It is important to provide them a space here they can learn together about each other, their struggles, differences, similarities and show dissent as democracy is not so much an "ideal" to be pursued as an "idealized" set of values that we must live and that must guide our life as a people (Apple and Bean, 2006: 83).

Education for Peace and working tools that aim toward the promotion of peace and nonviolence, seeks to catalyse an open knowledge transfer of these methods among people around the world by building networks, establishing communication tools and meeting people to bring new ideas. Children are human beings and their experience is important in building their identity in the society. Abuse of children and their experience of violence "cannot be looked at in isolation as one related only to sexual harassment but rather as an issue related to children and to childhood; sex and sexuality, violence and violation; and at a deeper level, power and domination, gender and patriarchy and so on" (Verma et al., 2013: 391). Peace is only possible when children experience equality, justice, democracy, secularism, relate school learning to their 'lived' experiences, and build new identities by transforming the 'Culture of Violence'. In the context of the movement for Bodoland, its conflict for identity, political autonomy vis-à-vis school education, may add further meaning to the discourse on 'Education for Peace'.

\section{Acknowledgement}

I would like to offer my gratitude to the reviewer and Dr Bhattacharyya for their critical inputs and comments, which have facilitated the author in giving final shape to the paper. 
Sharma. Space and Culture, India 2013, 1:1

http://www.spaceandculture.in/index.php/spaceandculture/article/view/15/5

Page 67

\section{About the Author}

Aparajita Sharma is also a professional social worker. She has experience of working with different marginalised communities, NGOs, state and even corporate groups for the last 7-8 years. Her areas of expertise are popular culture, ideology, pedagogy (both vocational and school education) gender and inclusive development. Experts in this field of work have critically acclaimed her works on 'Hegemony and Education', 'Conflicting interests in school education.

\section{References}

Apple, M. W. (1982). Education and Power, U.S.A: Routledge and Kegan Paul Ltd

Apple, M. W. and Beane, A. J. (2006). Democratic Schools: Lessons from the Chalk Face, Bhopal: Eklavya Publication

Barth, F. (1969). Ethnic Groups and Boundaries: The Social Organization of Cultural Difference, Boston: Little, Brown

Bajaj, M. (2004). Human rights education and student selfconception in the Dominican Republic, Journal of Peace Education, 1 (1), 21-36

Bernstein, B. and Landis, W. (1974). Selection and Control. Routledge: London.

Brahma, Y.Z., Narzihary, R.R., Brhama, U.G., Basumatary, U.K. and Brahma, D. (2001). Bodoland Movement 1986200: A Dream and Reality, Guwahati: Saraighat offset press

Boulding, E. (1976). The Underside of History: A View of Women through Time, New York: Halsted

Burns. R. and Aspelagh R. (1996). Three decades of peace education around the world. An anthology, New York: Garland

Cowen, R. (2000). Comparing futures or comparing pasts?, Comparative Education, 36(3), 333-342

Diaz-Soto, L. (2005). How can we teach peace when we are all so outraged? A call for critical peace education, Taboo: The Journal of Culture and Education, 9(2), 9-16

Datta, N. (2012). Questions of Identity in Assam- Location, Migration and Hybridity, New Delhi: Sage publication

Freire, P. (1970). Pedagogy of the oppressed, New York: Continuum

Friere, P. (1973). Education for critical consciousness. New York: Continuum
Giroux, H. A. (2001). Public Spaces Private Lives: Beyond the Culture of Cynicism, USA: Rowman and Littlefield Publishers.

Galtung, J. and Vincent, R.C. (1992). Global Glasnost: Toward a New World Information and Communication Order, London: Routledge

Galtung. J. (1978). Peace and Social Structure, Romania, ILEXIM, Bukuresti

Haavaelsrud, M. (2008). Conceptual perspectives in peace education, In M. Bajaj (ed.). The Encyclopedia of peace education, Charlotte, NC: Information Age Publishing, 4958

Haavelsrud, M. (1996). Education in developments. Norway: Arena Publishers.

Hicks, D. (1988). Education for Peace: issues, principles and practice in the classroom, London: Routledge

Hoare, Q. and Mathew, J. (1977). Selection from Prison Notebooks, London: International Publications

Herbert, R. (2012). Education for Peace, New York: Routledge

Jenkins, R. (2008). Social Identity, New York: Routledge

Karabel, J. and Halsey, A.H. (1977). Power and Ideology in education, New York: Oxford University Press

Kinnvall.C. (2004). Globalisation and religious nationalism: self, identity and search for ontological security, Social Psychology, 25(4), 741-767.

Kumar, K. (2001). Prejudice And Pride-School Histories of the freedom struggle in India and Pakistan, India: Penguins

Kumar, K. (2007). A pedagogues Romance, New Delhi: Sage Publication

Little, A. (2000). Development studies and comparative education: context, content, comparison and contributors, Comparative Education, 36(3), 279-296

Mclaren, P. (2002). Life in schools: An introduction to critical pedagogy in the foundation of education, Boston: Allyn and Bacon

Nongbri, T. (2005). Gender, Matrilini and Entrepreneurship: The Khasis of North-East India New Delhi: Zubaan.

NCF (2005). National Curriculum Framework, New Delhi: NCERT

Reardon, B. (1988). Comprehensive peace education, New York and London: Teachers College Press

Rieff, D. (1999). A new age of liberal imperialism?, World Policy Journal, 16(2), 1-10 
Sharma. Space and Culture, India 2013, 1:1

http://www.spaceandculture.in/index.php/spaceandculture/article/view/15/5

Rothman, J. (1997) Redefining identity based conflicts, San

Francisco: Jassy Bass

Toh, S.H. and Cawagas, V. (1990). Peaceful theory and practice in value education, Quezon City: Phoenix publishing House

Verma, J.S. Seth, L. and Subramanium, G. (2013). Report of the Committee on the Amendments to criminal law

Webel, C. and Galtung, J. (2007). Handbook of Peace and Conflict Studies, New York: Routledge

Wulf, C. (ed). (1974). Handbook on peace education, Frankfurt: International Peace Research Association 